\title{
Traditional uses of medicinal plants practiced by the indigenous communities at Mohmand Agency, FATA, Pakistan
}

Muhammad Abdul Aziz', Muhammad Adnan', Amir Hasan Khan², Abdelaaty Abdelaziz Shahat ${ }^{3,4}$, Mansour S. Al-Said ${ }^{3}$ and Riaz Ullah ${ }^{3}$

\begin{abstract}
Background: Plant-derived products have an imperative biological role against certain pathogenic organisms and were considered to be a major source of modern drugs. Rural people residing in developing countries are relying on traditional herbal medical system due to their strong believe and minimum access to allopathic medicines. Hence, ethnomedicinal knowledge is useful for the maintenance of community's based approaches under this medical system. Present study was carried out in an unexplored remote tribal area of Pakistan to investigate and document the existing ethnomedicinal knowledge on local flora.
\end{abstract}

Methods: Data was collected through semi-structured questionnaires from the community members and local herbalists. Use reports (URs) were counted for each species and analyzed through Linear Regression between the number of URs per family and number of plant species per family.

Results: A total of 64 medicinal plant species were recorded belonging to 60 genera and 41 families. Most frequently used plant families in ethnomedicines were Lamiaceae (8 species) and Asteraceae (7 species). Highest URs were recorded for Caralluma tuberculata N.E. Br. (49 URs) being followed by Thymus serphyllum L. (49 URs), Fagonia cretica L. (47 URs), Plantago lanceolata L. (45 URs), Periploca aphylla Decne. (44 URs), Citrullus colocynthis (L.) Schrad. (44 URs), and Sideroxylon mascatense (A.DC.) T.D.Penn. (44 URs). New ethnomedicinal uses were reported for Boerhaavia elongata Brandegee and Fumaria officinalis L. with confidential level of URs from the study area. Nineteen groups of health conditions were recorded during the course of study being treated with medicinal plants. Maximum number of 30 plant species was used to treat digestive problems. Most widely practiced mode of drugs' preparation and administration was powder. Leaves (30\% plants) were the most frequently used plant parts in the preparation of ethnomedicinal recipes.

Conclusions: Current study is an important addition to the field of ethnomedicines. The study reports important medicinal plants from an area, which has not been investigated previously. Traditional knowledge is restricted to health practitioners and elder community members. This knowledge is at the verge of extinction because younger generation is not taking interest in its learning and preservation process. Hence, there is a dire need to phytochemically and pharmacologically test the investigated taxa for the validation of traditional knowledge.

Keywords: Traditional knowledge, Herbal medicines, Use value, Relative frequency of citation

\footnotetext{
*Correspondence: amirhasankust@gmail.com

${ }^{2}$ Department of Botany, Shaheed Benazir Bhutto University Sheringal, District

Dir (Upper), Khyber Pakhtunkhwa, Pakistan

Full list of author information is available at the end of the article
} 


\section{Background}

Plant resources have remained an integral part of human society throughout history. World Health Organization (WHO) estimated that about $80 \%$ of the developing world's population use traditional herbal medicines [1]. In developing countries, traditional medicines provide a cheap and alternative source for primary health care [2-4] due to lack of modern health facilities, their effectiveness, cultural priorities, and choices [5-7]. In developed nations, usage of traditional herbal medicines is also a fast growing phenomenon. For instance in China, traditional herbal preparations account for $30-50 \%$ of the total drug consumption. While at the same time, in countries such as Nigeria, Ghana, Zambia, and Mali, the first choice for $60 \%$ children suffering with high malarial fever is herbal medicines. In Ethiopia, about $80 \%$ of the population use traditional medicines due to the cultural acceptability of healers and local pharmacopeias, comparatively low cost of traditional medicines and lack of access to modern drugs [8]. The documentation of ancestral knowledge in ethnobotanical surveys may cover the existing gap to discover effective drugs [9].

Pakistan is comprised of various climatic zones with unique biodiversity and consists of 6000 plant species, of which approximately 400-600 species are considered to be medicinally important $[10,11]$. In the country, several studies have reported the medicinal uses of plant resources [12-19].The folk knowledge on traditional herbal remedies usually transfer from one generation to another generation through oral way [18-21]. In vertical transfer, chances of elimination of knowledge are going in parallel, which poses a huge threat and need to be addressed for preservation. In the last few decades, a significant trend in scientific and commercial interests has been observed due to the cultural acceptability and economic potency of plant-based herbal products across the country [21, 22]. The country has diverse cultures and a variety of languages spoken predominantly in rural and remote areas. People from rural areas have minimum access to healthcare services, which is one of the main reasons for the utilization of traditional herbal medicines in such cultures [23].

Mohmand Agency is a remote tribal area of Pakistan, which is rich and diversified in important medicinal plants. Modernization and exposure to modern pharmaceuticals have significantly affected the traditional practices in the area. The ethnomedicinal knowledge in the study area is gradually heading towards extinction because the old age community members being the main bearer of this knowledge are passing away and younger generation is not interested to take it. Herbal practitioners in the area have sufficient traditional knowledge, but mostly, they are reluctant to disclose it to other community members.
Hence, the current study was planned with the objectives to record the traditional knowledge of study area, preserve it in the form of publish literature, and share it with other communities across the globe.

\section{Methods \\ Ethnographic and socioeconomic background of the study area}

Mohmand Agency is a part of Federally Administered Tribal Areas (FATA) of Pakistan and established in 1951. The Agency is bordered by Bajaur Agency to the north, Khyber Agency to the south, Malakand and Charsadda districts to the east, Peshawar district to the southeast, and Afghanistan to the west (Fig. 1). Mohmand Agency takes its name from the Mohmand tribe living in the area. Total area of the agency is $2296 \mathrm{~km}^{2}$ with headquarter located at Ghalanai area. Geographically, the area is comprised of rugged mountains with barren slopes and widespread along the banks of Kabul River. Lower Mohmand area is rather fertile whereas Upper area is comparatively less productive. Most of the agricultural land is rain fed with insufficient rainfall. Mohmand tribe is also migrated to the fertile lands of district Charsadda and Mardan due to less rainfall ratio and water for irrigation at their homelands. According to the report published by the Pakistan Bureau of Statistics (2017), the current human population of Mohmand Agency is 466,984. Mohmand is the major tribe in the agency which is further subdivided into Tarakzai, Halimzai, Khwaezai, Baezai Safi, and Utmankhel.

The socioeconomic condition of indigenous community is heterogeneous and comparatively poor. The income sources were limited in general except from agriculture and some trade/businesses. Mostly, the people are farmers by profession, while others are government servants, and some have their own small-scale businesses, while some people work on daily wages. Some locals are serving in Gulf States and supporting their families through remittances. People keep domestic animals at their homes, which is a sign of better socioeconomic condition of a tribe or family. There are few secondary schools and only three government colleges in the Agency. There are some public health dispensaries facilitating the people to some extent; however, people residing in remote hilly areas have low or no access to the allopathic medicines. Local communities tend to use traditional herbal therapies as compared to modern pharmaceuticals. They have strong cultural beliefs and faiths about the herbal medicines prepared by the traditional healers locally known Hakim(s). Traditional knowledge about the herbal recipe is restricted to these Hakims and other elder community members. The socioeconomic background of the indigenous communities can be uplifted if the cultivation and sustainable utilization of medicinal plants is promoted and encouraged in the area. 


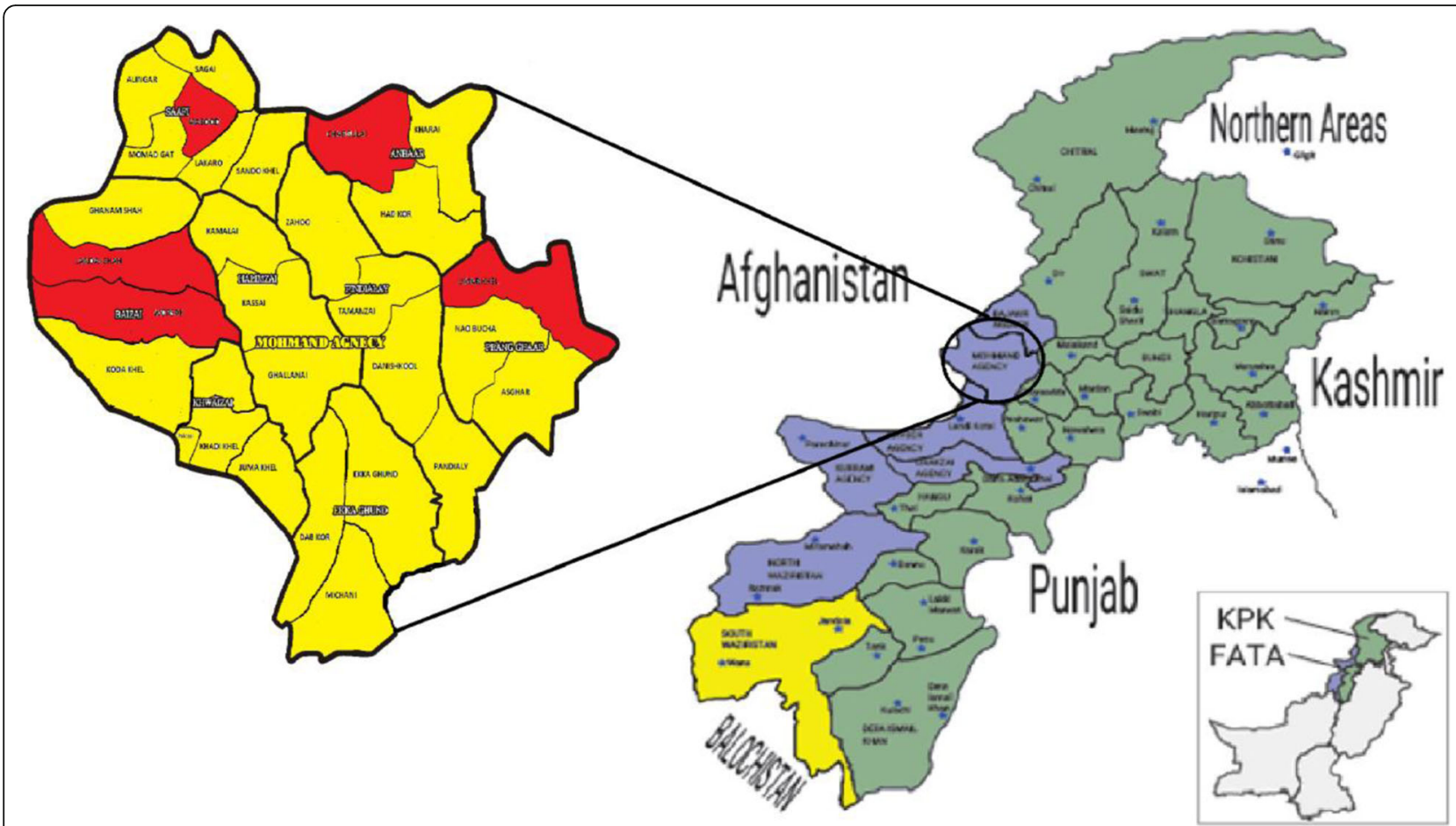

Fig. 1 Study area map of Mohmand agency

\section{Informant selection and ethnomedicinal data collection}

Field survey for ethnomedicinal data collection was carried out between May and August 2016. Regular field visits were undertaken prior to data collection in order to ensure and acknowledge the support of the indigenous communities. Local informants were identified for interviews in the month of May, while ethnomedicinal data was recorded in the rest of 3 months. Being local occupant of the study area, Mr. Amir Hasan Khan visited various sites along with volunteer team comprised of a pharmacist and plant taxonomist. The team managed several meetings with the local representatives of the community to whom purpose of the study was presented. Data was collected from community members through semi-structured interviews, meetings, and group discussions at various public places following the procedure adopted by Martin [24]. A total of 81 local key respondents were selected, which include 57 males and 24 females of various age groups through snow ball sampling technique (Table 1). The total respondents also comprised of 14 traditional herbal practitioners locally called Hakims. With exception of some elder females, young female community members were not allowed to participate in interviews due to cultural limitations. The selection of respondents was based on their high reputation in ethnomedicinal knowledge. We ensured the validity of the traditional knowledge by maintaining continuous relationships with the local peoples in the course of survey.
All interviews with the local people were conducted in local language "Pashto". In order to get trust and consent, objectives of the study were shared with survey participants. Most of the data on traditional therapies was taken from the local healers. Post data collection, the survey results were redisplayed to the informants for removing errors and omissions from the data.

Table 1 Demographic data of the respondents

\begin{tabular}{ll}
\hline Category & Total \\
\hline Gender & 57 \\
Man & 24 \\
Female & \\
Age group & 8 \\
$28-40$ & 73 \\
$>40$ & \\
Education & 45 \\
Illiterate & 9 \\
Primary & 12 \\
Middle & 14 \\
Secondary & \\
Occupation & \\
House wives & 24 \\
Farmers & 30 \\
Labors & 13 \\
Local healers & 14 \\
\hline
\end{tabular}




\section{Preservation and taxonomical verifications of plant species}

Medicinal plants collected during field visits were identified by Dr. Abdul Haq at the Department of Botany, Postgraduate College Khar, Bajaur, Pakistan. The plants were dried under the shade and poisoned with $1 \% \mathrm{HgCl}_{2}$, pressed and mounted on herbarium sheets. Each herbarium sheet was given a voucher name and number and submitted to the department for future use as a ready reference. Taxonomic problems regarding the correct name and updated systematic position were resolved by using the online database "The Plant List" (www.theplantlist.org).

\section{Data analysis}

Data recorded during the survey was subjected to regression analysis between the URs and number of species per family by using SPSS (16 Version) [25].

\section{Results and discussion}

\section{Status of the traditional knowledge and role of Hakim}

Local communities of Mohmand Agency have their own rural culture and beliefs. Their traditional life style including use of herbal medicines make them closer to the natural resources and distinguish from other cultures across the country. It is a natural phenomenon that each community across the globe has a unique philosophy, belief, attitude, culture, and economic status. These are the basic factors, which are responsible for the variation in practicing traditional medicines [26]. The pattern of utilization of medicinal plants in a particular community is a part of its cultural traditional knowledge, passing from one generation to another generation representing a heritage. In the past, several studies have reported the uses of medicinal plants in a single culture or one ethnic group while little attention given to their comparative analysis across various communities and cultures [27]. However, in the last few decades, intercultural importance of medicinal flora has been highlighted among different ethnic groups across the globe [19, 28-32]. This comparisonal approach is practical and essential for finding cross cultural variations and future research prospects on medicinal plants [19].

Current study is an important addition towards the preservation of folk ethnomedicinal knowledge on plants and the efficacy of their derived products from an area not been previously explored. In this study, we have observed that educated people were less conversant compared to the ones with little education in using traditional therapies. Moreover, herbal practitioners hold a large part of the ethnomedicinal knowledge while the aged people only possess a small fraction of this knowledge. In the area, traditional knowledge is under the threat of extinction. The erosion of traditional knowledge is mainly due to the slow and gradual introduction of allopathic medicines, current trend towards modernization, and exposure to technological era. Younger generation is least interested in using herbal therapies; rather, they are more tilted towards allopathic medicines. Similar tendency has been found in other studies [14, 33]. Therefore, the issue of preserving ethnomedicinal knowledge must be properly addressed; otherwise, the vertical and horizontal transfer rate of this knowledge within and across communities would be reduced and ultimately extinct in the near future. This concern has already been elevated in similar studies [34, 35].

Most of the Hakims in the study area were using Unani or Ayurvedic system of traditional medication for the treatment of different diseases. Usually, they belong to the local community and have better understandings about the patients' background, which also facilitates them in disease treatment process. These local herbalists usually diagnose any disease through patient's symptoms and assessment of the pulse. The Hakims interviewed during the study were males, of whom very few were qualified professionals. The local people were of the view that consultation process with the local herbalists mainly depends on personal experiences of these practitioners. However, the introduction of modern pharmaceuticals has triggered the tendency to utilize allopathic medicines and brought cultural changes in the society. Hence, the local dependency on traditional medicines has been significantly decreased as also indicated by Adnan et al. [36].

\section{Quantitative ethnobotany and preparation of herbal therapies}

A total of 64 medicinal plant species belong to 60 genera, and 41 families were catalogued in the study area, which were used for the treatment of several types of human's diseases (Table 2). Most of the reported plant species belong to the family Lamiaceae (8 species; URs $=236$ ) followed by Asteraceae (7 species; URs $=118)$, Apocynaceae $(4$ species; URs $=141)$, Brassicaceae (4 species; URs $=92)$, Malvaceae (3 species; URs =93), Fabaceae (2 species; URs = 50), Fumariaceae (2 species; URs $=46)$, Moraceae (2 species; URs = 53), Rhamanaeae (2 species; URs = 79), Umbelliferae (2 species; URs =72), and Zygophyllaceae (2 species; URs = 86). In our study, a significant correlation $(r=86)$ has been observed between the URs and number of species per plant family (Fig. 2). The concept of regression was introduced by Moerman [25] to examine patterns of medicinal plant use, based on taxonomic affiliation. This method includes the following: (i) linearly regress the number of species in a family against the number of medicinal species in the family for a specific geographic region, (ii) interpret least squares line as a measure of average relationship between family size and number of medicinal 


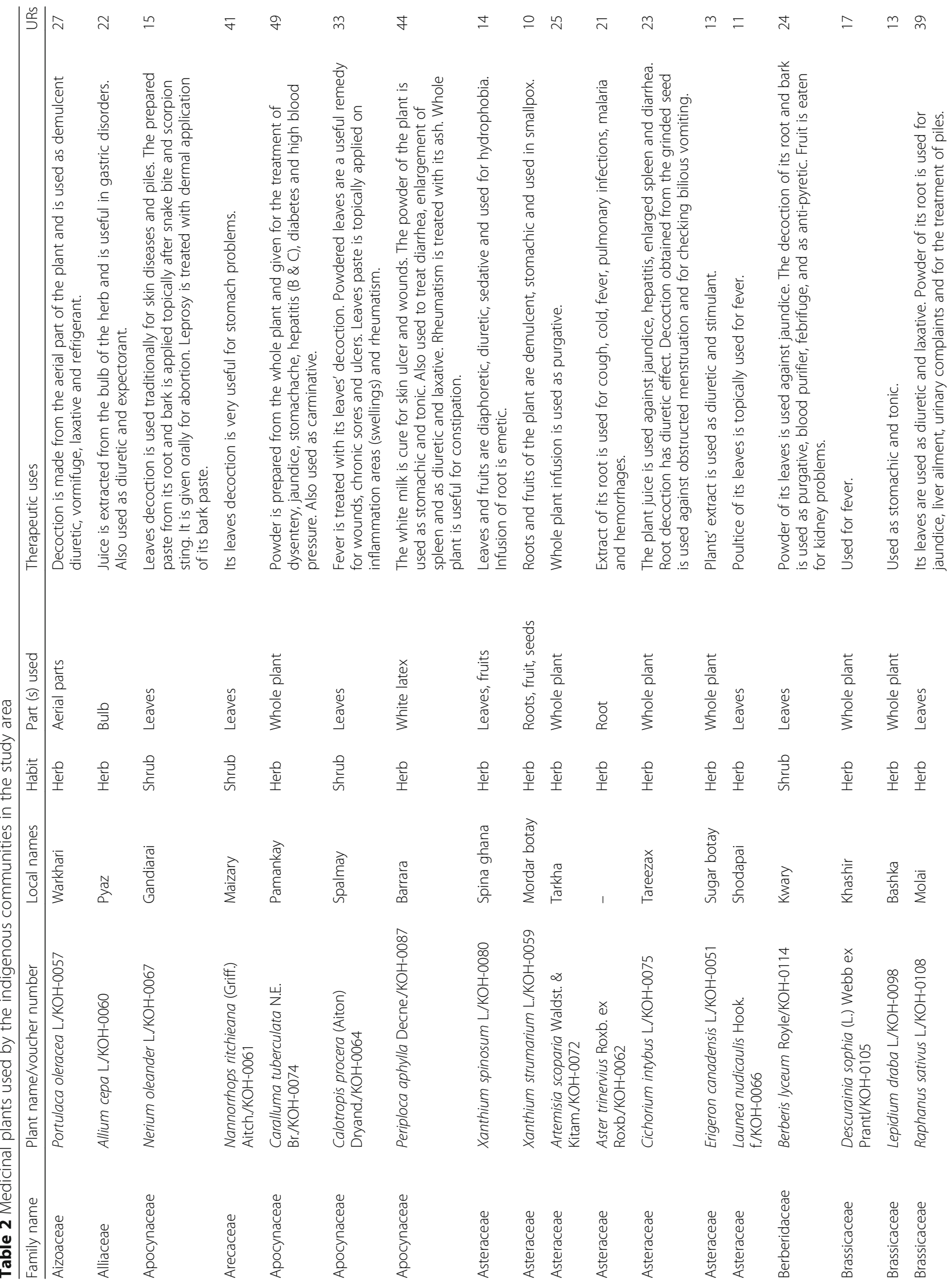




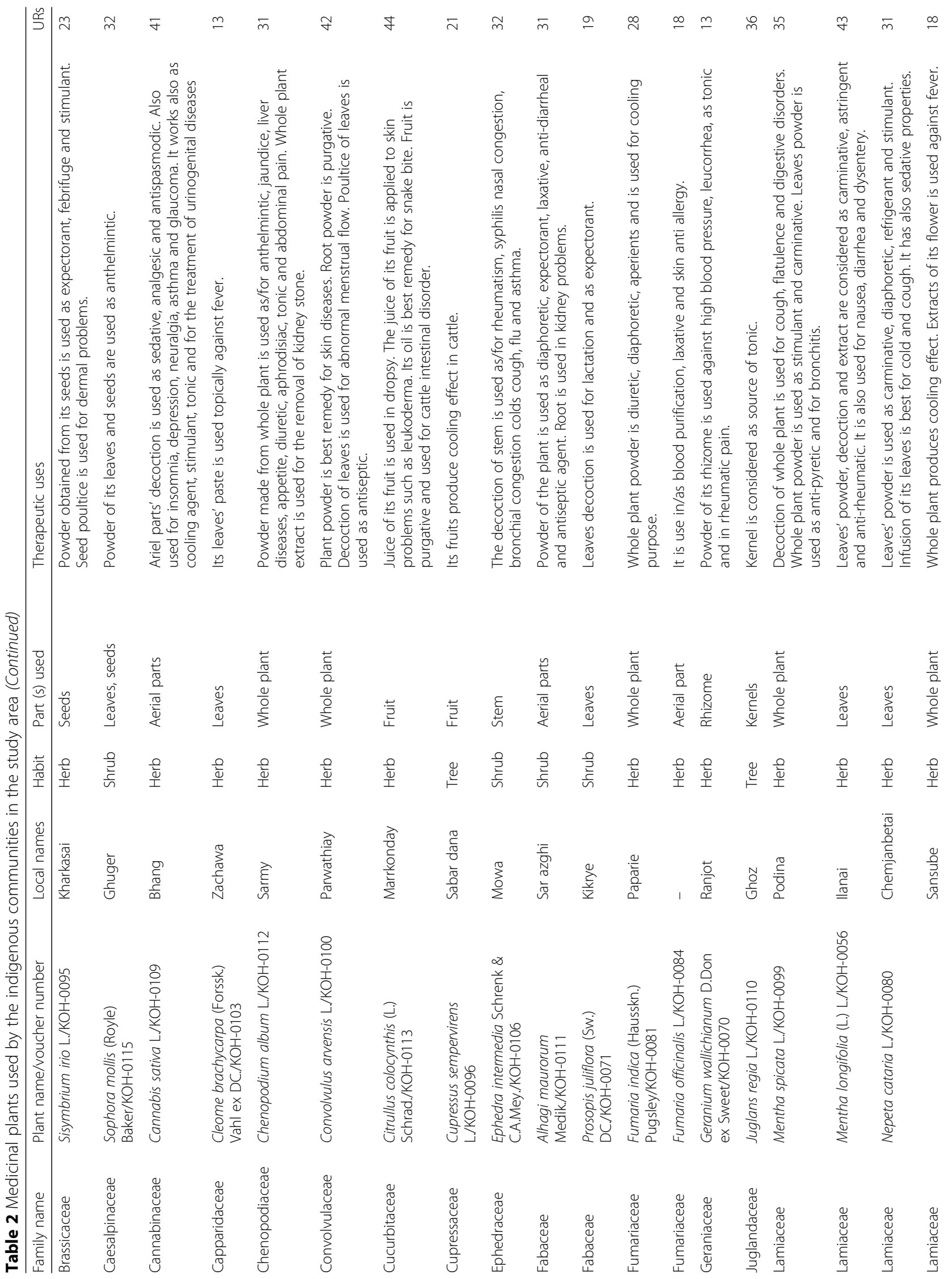




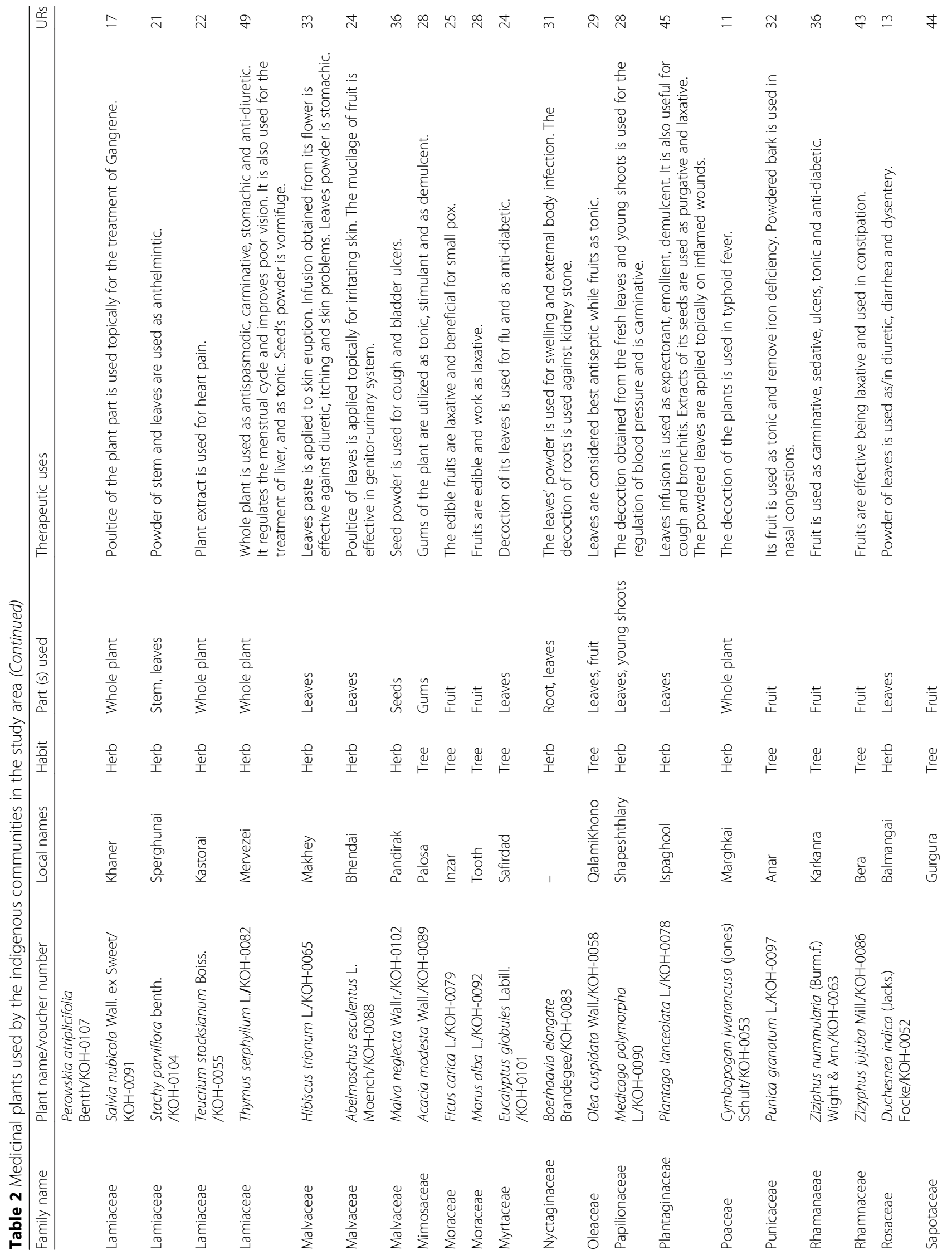




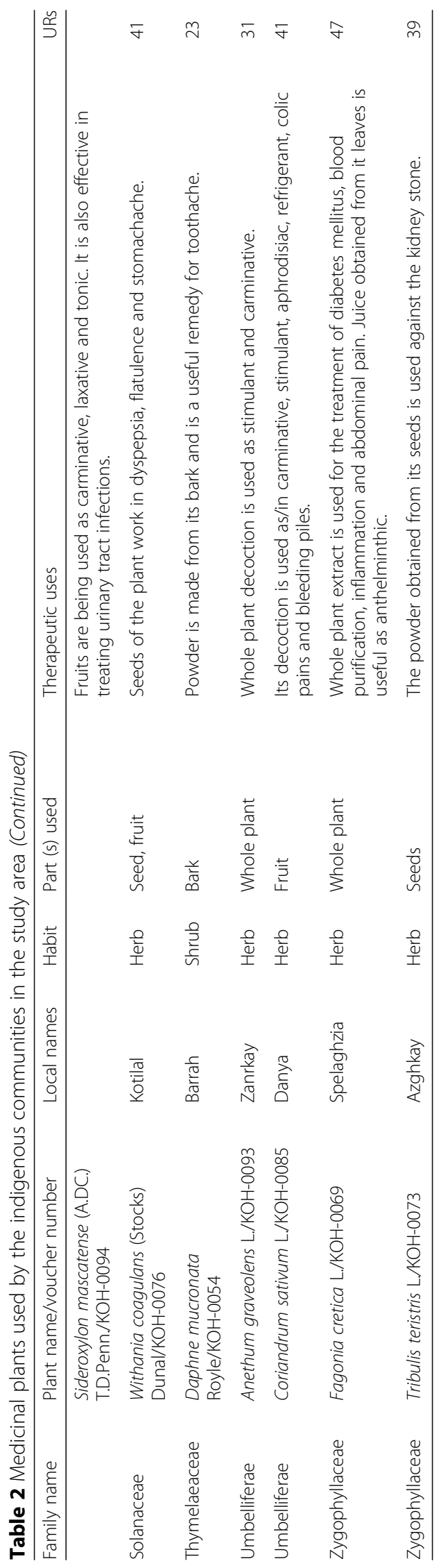




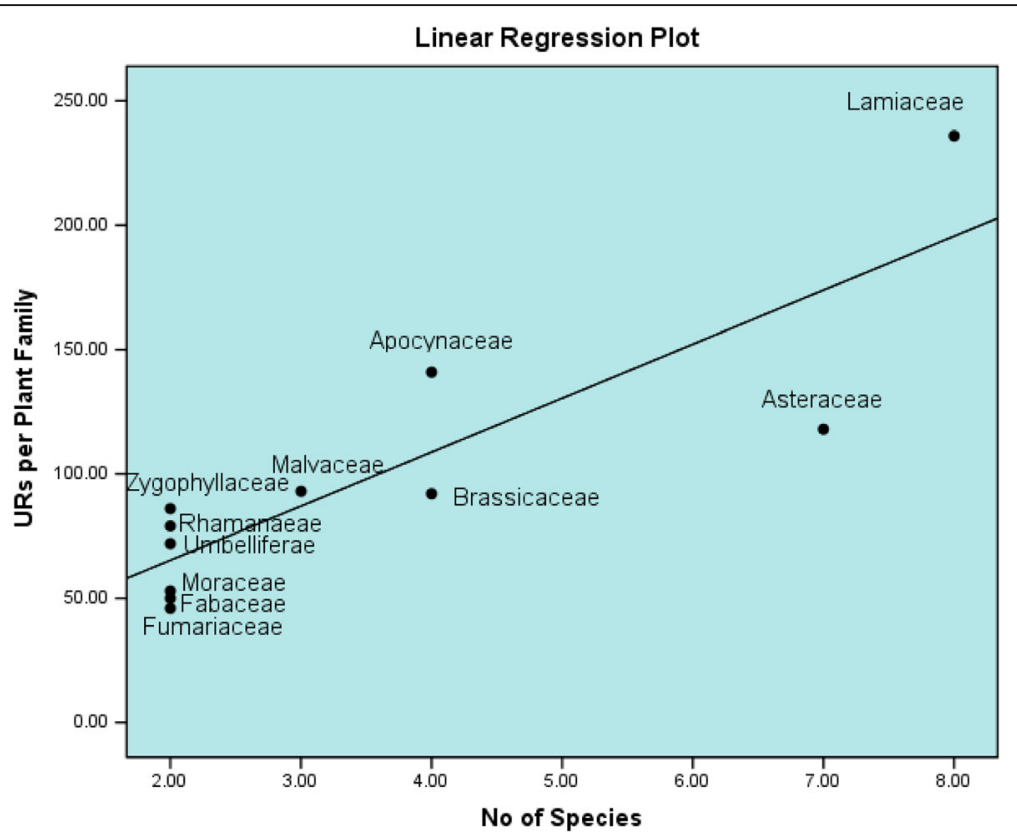

Fig. 2 Linear regression between URs per family and number of plant species per family

species, and (iii) use regression residuals to assess medicinal over- or underutilization of groups.

Our results on most reported plant species from Lamiaceae family are in line with previous studies on various cultures [17, 37-39]. The local importance and acceptance of any plant family may be referred to the presence of active phytochemicals, which may be effective in certain pathological conditions [40]. Additionally, the reason behind the usage of a specific family may be due its predominance in a geographical area as well as familiarity among the local people.

Out of the reported 64 medicinal plants, herbaceous (68\%) life form was dominantly used in drug preparation. The most frequent plant parts were leaves (30\%) followed by whole plants (20\%) and fruits (16\%) (Fig. 3). Herbaceous life form and leaves' usage in ethnomedicinal recipes have been reported in several studies [12, 41-43]. The leaves and aerial plant parts are active in the process of autotrophy and metabolism and can be easily collected [44-47]. However, in Traditional Chinese Medicines (TCM), roots have been indicated as the dominant part in recipes preparation $[48,49]$. The composition of a particular ethnomedicine varies from species to species as for one species the active part could be the leaf while for other it may be root. In any case, phytopharmacological screening of all plant parts is necessary to validate the local traditional knowledge and search new compounds for the modern allopathic medicines. In this study, various methods of drug preparation and administration have been documented, which were being applied by the local herbalists. Mainly, the ethnomedicines were administered orally along with other additives. Our results are in line with other studies, in which

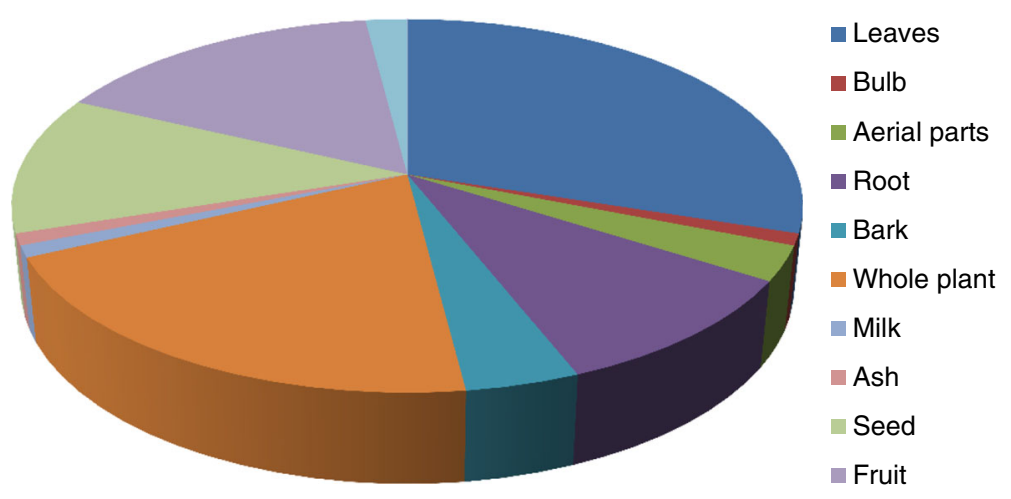

Fig. 3 Most frequently used plant parts in the study region 
ethnomedicines were utilized along with some solvents/additives to reduce the bitter taste of the remedy, mitigate the toxic consequences such as vomiting and diarrhea, and maximize drugs' efficiency [17, 50, 51].

In terms of oral use of herbal recipes, mainly, the plant powder was ingested with water or as decoction and very rarely juice was extracted (Fig. 4). These findings are similar to the previous studies $[13,52]$. On the other side, paste and grinded herbs were extensively used to treat a particular dermal disease. Other studies have also reported the decoction as the widely accepted administrative form of herbal medicines [17, 41, 53]. Reported medicinal plants were used for various health conditions and diseases. Most of the remedies were based on single plant's application due to palatability, non-toxicity and high efficacy [41]. Some remedies were prepared in a combination of two or more plants to gain maximum therapeutic effect (synergism).

A total of 19 groups of health conditions were recorded based on symptoms (Fig. 5). The local herbalists usually diagnose a specific ailment by symptoms and signs, while not using the modern laboratory techniques. Highest number of plants were used for digestive problems (30 species) followed by as tonic (13 species) and diuretic (13 specie) (Fig. 5). These results are in parallel with the previous findings reported from various parts of the country $[18,19,36,54-56]$, in which gastrointestinal complaints were declared common. The existence of digestive disorders as a main use category in the study area may be due to the ingestion of contaminated foods and other toxic explosive material produced as a result of previous armed conflicts in the area. Furthermore, lack of proper sanitation, less access to clean water, and fuel wood's smoke inhalation may contribute to gastric problems. Gastrointestinal disorders are predominant across the globe, for which a large number of medicinal plants are being used by different cultures $[27,46,47,49,52,57-60]$. In the study area, local people are aware of the toxic consequences of some orally used medicinal plants such as Nerium oleander L. and
Calotropis procera (Aiton) Dryand. These plants can cause nausea and vomiting in humans and death of cattle if not properly administered.

\section{Important medicinal plants}

Traditional knowledge of medicinal plants has contributed to the modern day pharmaceutics in the form of important drugs. As an example, these include quinine (Cinchona succirubra), colchicines (Colchicum autumnale), digitalis glycosides (Digitalis spp.), morphine, codeine, papaverine (Papaver somniferum), physostigmine (Physostigma venenosum), and pilocarpine (Pilocarpus jaborandi) [61]. Hence, the need for searching new products from medicinal plants is essential component for the current and future generations.

In our study, the importance of a medicinal plant species was indicated by use reports (URs). Maximum URs were recorded for Caralluma tuberculata N.E. Br. (49), Thymus serphyllum L. (49), Fagonia cretica L. (47), and Plantago lanceolata L. (45). Other plants are important for the indigenous communities; however, they were reported with lower URs. Moreover, new uses of Boerhaavia elongata Brandegee and Fumaria officinalis $\mathrm{L}$ have also been recorded in this study. These species are being discussed as follow:

\section{Caralluma tuberculata N.E. Br.}

C. tuberculata locally known as Pamankay is extensively used against jaundice, dysentery, stomach pain, high blood pressure and as carminative in the area. In addition, the plant is also being utilized as vegetable and carry high price $(4 \mathrm{USD} / \mathrm{kg})$ in the local market. In Pakistan, wild and cultivated C. tuberculata is traditionally used in tea for the treatment of diabetes [62].

In Quetta (Pakistan), there is a tradition for the treatment of high blood pressure by chewing fresh plant of C. tuberculata after each meal, thrice a day for 1 month [62]. The plant is also utilized for blood purification in South Africa, Saudi Arabia, and Iran [62-64]. Reports

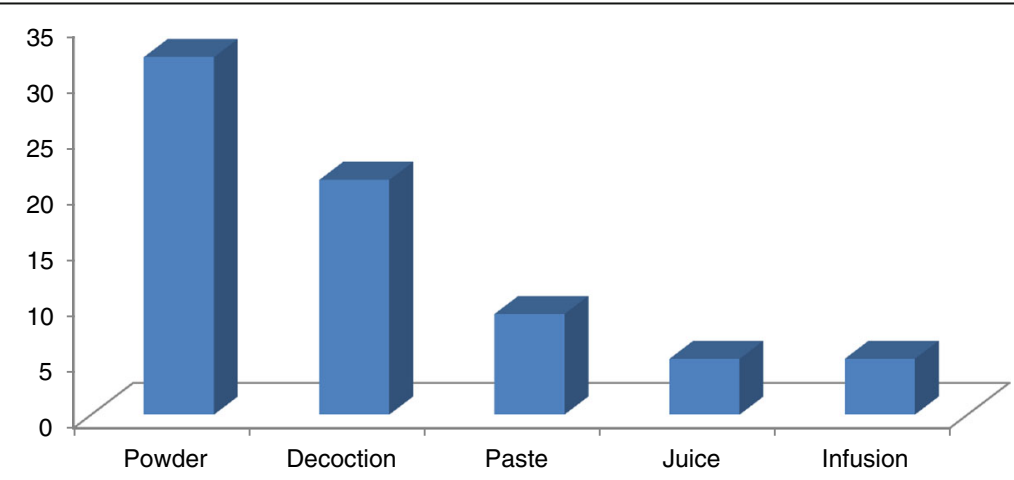

Fig. 4 Preparation methods of herbal medicines 


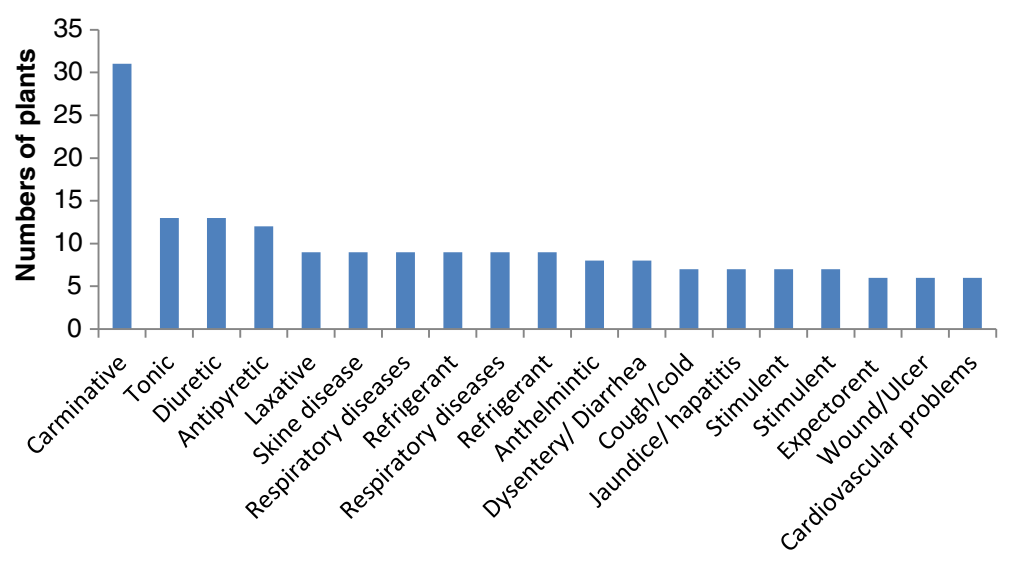

Fig. 5 Number of plants used to treat different ailments in the study area

have shown its uses for the treatment of digestive disorders such as diarrhea, ulcer, constipation, and abdominal pain [63, 65-67]. Skin problems are also being treated by the use of this plant in Pakistan, India, Nigeria, Iran, Saudi Arabia, and Oman [62, 64, 68]. Furthermore, chewing of fresh plant is considered effective in pimples, freckles, blood purification, rheumatism, and pyrexia [67, 69-71]. Caralluma extracts cause the secretion of synovial fluids, which enhances joints mobility and efficiency. The aerial parts of the plant have been scientifically validated for anti-malarial activity [70].

Khan et al. [14] reported that the methanolic extract of C. tuberculata has inhibited the growth of Aspergillus flavus and Aspergillus niger. Parekh and Chanda [72] have also found its antifungal activity against Pheretima posthuma and Candida albicans. Moreover, chloroform and methanolic extracts of $C$. tuberculata have shown antioxidant activity [73]. Its ethyl acetate extract was found to be the most potent anti-proliferative fraction against breast cancer and other tumor cell lines while the steroidal glycosides were found to possess moderate micromolar cytotoxic activity on breast cancer and other cells [74]. Ethanolic and aqueous extracts of C. tuberculata have shown hypoglycemic activity at a dose of $70.42 \mathrm{mg} / \mathrm{kg}$ in allaxon-fed diabetic male Albino rats [75]. Various research studies have indicated that the bioactivities of $C$. tuberculata might be due to the presence of certain classes of compounds including pregnane glycosides, flavonoid, flavones, and glycosides [36].

\section{Thymus serphyllum $L$.}

T. serphyllum is widely used as antispasmodic, carminative, stomachic, tonic, and anti-diuretic in the study area. It regulates the menstrual cycle, improves the poor vision, and is used for the treatment of liver disorders. Studies conducted in different parts of the world have shown that the aerial parts of $T$. serpyllum has a long tradition in Europe [76] and worldwide as anthelmintic, antiseptic, antispasmodic, carminative, deodorant, diaphoretic, disinfectant, expectorant, sedative, and tonic [77]. It is most frequently used for gastric problems and respiratory problems $[78,79]$. In Western Balkans, the species is used as a sedative [80], improving blood circulation, anticholesterolemic and immunostimulant [81]. In the alpine region of northeastern Italy, infusion or decoction of plant's aerial parts is used for the treatment of rheumatism [82]. Gairola et al. [32] mentioned the use of wild thyme in some regions of India for the treatment of menstrual disorders while Shinwari and Gilani [83] confirmed its use as an anthelmintic in the Northern Pakistan. T. serpyllum is also used externally as an antiseptic and wound-healing agent [84-86].

Over the last two decades, attention has been given to investigate the chemical composition of $T$. serpyllum's essential oil [87-91]. According to the Physicians' Desk Reference (PDR) for Herbal Medicines, the chief component of essential oil is carvacrol, while it also contains borneol, isobutyl acetate, caryophyllene,1,8-cineole, citral, citronellal, citronellol, $p$-cymene, geraniol, linalool, $\alpha$-pinene, $\gamma$-terpinene, $\alpha$-terpineol, terpinyl acetate, and thymol in relatively high concentrations [92]. According to European Pharmacopeia, T. serpyllum contain at least $1.2 \%$ essential oil, out of which the total content of carvacrol and thymol is $40 \%$ or higher [93]. In addition to the essential oil, wild thyme also contains flavonoids, phenol carboxylic acids and their derivatives, triterpenes and tannins [92, 94]. Kulisic et al. [95] also reported $\gamma$ terpinene and p-cymene among the main components of the essential oil. The compositions and concentrations of compounds in the essential oil of T. serpyllum are significantly different across Pakistan and worldwide. For instance, the essential oil of $T$. serpyllum growing in Pakistan contains mainly thymol (53.3\%) and carvacrol (10.4\%) [88], while another study by Hussain et al. [89] reported carvacrol (44.4\%) and ocymene (14.0\%) from the Gilgit valley of Pakistan. Hazzit et al. [96] found that 
the antioxidant potential of T. serpyllum may be attributed to the phenol constituents of essential oil, which justifies the traditional uses of wild thyme. However, the antioxidant activity of its essential oil is not only due to the presence of certain dominant components but also the synergism of a larger number of compounds in small amounts including trans-nerolidol, germacrene $\mathrm{D}, \beta$ cadinene, and $\delta$-bisabolene [26].

Antimicrobial assays revealed that ethanol and aqueous extracts of $T$. serpyllum carries inhibitory activity against Staphylococcus aureus, Bacillus subtilis, Escherichia coli, Pseudomonas aeruginosa, Proteus mirabilis, Salmonella choleraesuis, Enterococcus faecalis, Salmonella Typhi, Shigella ferarie, Bacillus megaterium, Bacillus subtilis, Lactobacillus acidophilus, Micrococcus luteus, Staphylococcus albus, and Vibrio cholera [88, 97, 98]. The hexane extract of the species demonstrated best anticancer activity against $\mathrm{HepG}_{2}$ (Liver Carcinoma Cell Line) followed by HCT-116 (Colon Cancer Cell Line), MCF-7 and MDAMB-231 (Breast Cancer Cell Lines), PC3 (Prostate Cancer Cell Line), and A549 (Lung Carcinoma Cell Line) [99].

\section{Fagonia cretica $L$.}

In our study, extract from the whole plant of F. cretica was utilized for curing diabetes mellitus, blood purification, as anti-inflammatory and for abdominal pain. The juice obtained from its leaves is used as anthelminthic. Aziz et al. [18] reported the extracts of F. cretica for the treatment of diabetes mellitus, scabies, gastric problems, expulsion of abdomen worms, blood purification and inflammation. The list of diseases treated by the F. cretica includes sore mouth and small pox [100]. Additionally, it is also used as hematological, neurological, endocrinological, dermatological, and anti-inflammatory, for small pox and endothermic reactions in the body [101, 102]; for cold and cough [103]; as astringent, febrifuge, thirst, vomiting, dysentery, asthma, urinary discharges, typhoid, toothache, stomach troubles and anti-tumor [104]. Similarities in plants' usage in the current study with that of previous studies may be due to similarities in floral composition, propinquity and other cultural values.

Pharmacological studies have shown that F. cretica carries anticancer, antimicrobial, antiviral, analgesic, antiinflammatory, antipyretic, antioxidant and thrombolytic activities [105]. Aqueous extract of $F$. cretica has anti-breast cancer effect without common side effects of standard cytotoxic therapy [106]. Methanolic extract has been reported as hemorrhagic inhibitor against snake venom as compared to standard antiserum [107]. The alcoholic extract of the plant exhibits significant inhibitory potential against Salmonella typhi a causative agent of typhoid fever [108]. Moreover, it has also shown inhibitory potential against Bacillus subtilis, Escherichia coli, Pseudomonas aeruginosa, Staphylococcus aureus, Staphylococcus epidermidis, and
Klebsiella pneumoni [109, 110]. Phytochemical investigation of the plant revealed the presence of alkaloids, flavonoids, terpenoids, saponins, tannins, coumarins, sterols, and glycosides in different polar and non-polar extracts of its parts [109-111]. Anjum et al. [112] isolated 11 new compounds from the $n$-hexane extract of $F$. cretica including Linoleic acid, b-sitosteryl-3-O-b-D-(60-hexadecanoyl)glucopyranoside, octacosonic acid, methyl triacantanoate, b-Amyrin acetate, taraxerol, oleanolic aldehyde acetate, triacontanoic acid, taraxerone,2a,3a,23 trihydroxyolean-12-en28-oic acid, 3a,23-dihydroxyrus-12-en-28-oicacid. Isolated compounds from $F$. cretica extracts indicated antifungal potential against Trichophyton longifusus, Candida albicans, Aspergillus flavus, Microsporum canis, Fusarium solani, and Candida glabrata strains. Among 11 isolated compounds, "taraxerol" has shown highest inhibitory effects against Aspergillus flavus with $90-\mathrm{mm}$ zone of inhibition compared to the $20 \mathrm{~mm}$ for Miconazole standard [112]. The pharmacological evidences of this rare plant in terms of antimicrobial, anticancer, and other activities suggest further clinical trials to validate its traditional uses.

\section{Plantago lanceolata $L$.}

Infusion obtained from the leaves of P. lanceolata is used as expectorant, emollient and demulcent in the study area. It is useful for cough, cold, fever and bronchitis while the extract is used as purgative and laxative. The powder obtained from the leaves is applied topically on inflamed wounds. In previous studies, $P$. lanceolata has been reported for the treatment of cough, bronchitis, and as stomachache, dysmenorrheal, expectorant, emollient, demulcent, astringent and laxative [18, 54, 79]. Phytochemical constituents isolated from this plant include silica, potassium, alphaamyrin, mucilage, zinc, glycosides, caffeic and tannins. Khalid et al. [113] revealed that Plantago has demulcent, astringent expectorant, having healing and soothing effect on intestinal mucosal layer. Reports have shown that the crude extract of $P$. lanceolata have the potential to combat with multidrug resistant $K$. pneumonia $[114,115]$.

\section{Boerhaavia elongata Brandegee and Fumaria officinalis $L$.}

Powdered leaves of $B$. elongate are used for swellings and external body infections while the decoction of its root is used against kidney stones. In the same way, $F$. officinalis is utilized for the cure of blood purification, skin problems, and allergy and as laxative. A detailed and comprehensive literature survey was carried out by investigating various bibliographic sources in order to sort out the novelty of the reported indigenous flora [12-18, 22, 42, 43, 54, 83, 88, 115-125]. After thorough search, no previous reports were found for the two medicinal plants. However, new medicinal uses were found with moderate number of URs from the study area for 
B. elongata and F. officinalis, which are scarcely mentioned in previous ethnobotanical studies across the country. Other important plants, which were commonly used by the local community having high URs, were Mentha longifolia (L.) L. (43), Zizyphus jujuba Mill. (43), Nannorrhops ritchieana (Griff.) Aitch. (41), Cannabis sativa L. (41), Withania coagulans (Stocks) Dunal (41), and Coriandrum sativum L. (41). These species require comprehensive phytopharmacological investigations to validate their efficacy and ensure their safe utilization.

\section{Threats to the indigenous flora}

During the field survey, certain important plants were found under the threat of anthrpogenic pressure. As an example, C. tuberculata and $N$. ritchieana were found endangered in their natural habitats due to over collection. These are the two species, which are harvested by the local people for economic benefits. The local people claimed that fuel wood collection, roads and homes construction, uncontrolled fire setting, fodder collection, and over-grazing are the possible factors responsible for the destruction of the natural habitats of the medicinal plants. The rate of such activities varies from place to place. People are unaware of the conservation of the medicinal plants. In addition to the aforementioned threats and processes, armed conflict in the area for the last one decade is an alarming concern for the conservation of the medicinal flora. The use of explosive material in the area has made several plants contaminated with corrosive material. Furthermore, no conservation strategies have been adopted in the study area to avoid overexploitation of the wild species. However, some plants are being cultivated and marketed by the farmers, which include Morus alba, Olea cuspidata, and Punica granatum. This local initiative of the indigenous communities to gain economic benefits from the local flora may promote the interest for the conservation and regulation of local flora to safeguard the threatened species [126].

\section{Conclusions}

This study has played an important role in the preservation of traditional knowledge from a remote area, where the folk knowledge is eroding at a faster rate due to several factors including the rapid modernization. The traditional knowledge is mostly in the custody of local herbalists and elder community members. The study has reported a total of 64 medicinal plant species belonging to 36 families. Lamiaceae and Asteraceae were the utmost used plant families in the study area. Species such as C. tuberculata and T. serphyllum have highest number of use reports and are mostly used by the local people. Two medicinal plant species including B. elongata and $F$. officinalis were reported with new ethnomedicinal uses with confidential level of citations from the study area. Certain medicinal plants have reportedly been screened phytochemically and tested pharmacologically; however, the traditional uses of a large number of plants still remain to be validated. Hence, our study stress on the need for the phytochemical, pharmacological, microbiological, toxicological, preclinical, and clinical investigations to ensure the safety and efficacy of the reported medicinal taxa. Our study also highlighted certain threats faced to the local flora including deforestation, heavy grazing, and overexploitation that are affecting the process of sustainability. Hence, sound conservation strategies need to be developed and implemented for the sustainable utilization of medicinal flora and preservation of traditional knowledge.

\section{Abbreviations \\ FATA: Federally Administered Tribal Areas; TCM: Traditional Chinese Medicines; URs: Use reports; WHO: World Health Organization}

\section{Acknowledgements}

The authors extend their appreciation to the Deanship of Scientific Research at King Saud University for funding this work through research group no RGP-262. We are also thankful to WWF, Peshawar, Pakistan, for technical and financial support in the field data collection. The authors are grateful to Izzat Ullah (Pharmacist) and Dr. Abdul Haq (Taxonomist). The authors are also thankful to the indigenous community for sharing their precious traditional knowledge. Authors express their best gratitude towards the traditional healers of the study area.

\section{Funding}

This research study did not receive any grant from any organization.

\section{Availability of data and materials}

The authors agreed not to share the data. Further, the authors do not agree to the data exposition prior to publication because any one can manipulate the data and may cause inconvenience.

\section{Authors' contributions \\ AHK carried out the field work. MAA compiled the data. MAA and AHK prepared the draft manuscript during first submission. In revised version of the manuscript, three other researchers, i.e., AAS, MSA, and RU, have been added as co-authors due to their technical supportive work and help during text incorporation for the improvement of the revised manuscript. These authors also did help in the analysis (new) of data manuscript. MA supervised all the stages of this study and provided comments on the draft manuscript. All the authors have read and approved the final manuscript.}

Ethics approval and consent to participate

Not applicable

Consent for publication

Not applicable

\section{Competing interests}

The authors declare that they have no competing interests.

\section{Publisher's Note}

Springer Nature remains neutral with regard to jurisdictional claims in published maps and institutional affiliations. 


\section{Author details}

'Department of Botany, Kohat University of Science and Technology, Kohat, Khyber Pakhtunkhwa 26000, Pakistan. ${ }^{2}$ Department of Botany, Shaheed Benazir Bhutto University Sheringal, District Dir (Upper), Khyber Pakhtunkhwa, Pakistan. ${ }^{3}$ Department of Pharmacognosy and Medicinal Aromatic, and Poisonous Plants Research Center, College of Pharmacy King Saud University, Riyadh 11451, Saudi Arabia. ${ }^{4}$ Phytochemistry Department, National Research Centre, 33 El Bohouth st., Dokki, P.O. Box 12622, Giza, Egypt.

Received: 12 June 2017 Accepted: 22 December 2017

\section{Published online: 09 January 2018}

\section{References}

1. Alves RR, Rosa IL. Why study the use of animal products in traditional medicines? J Ethnobiol Ethnomed. 2005;1 (1):5.

2. Bannerman RH, Burton J, Chen WC. Traditional medicine and health care coverage: a reader for health administrators and practitioners. WHO. 1983:318-27.

3. Manandhar NP. Native phytotherapy among the Raute tribes of Dadeldhura district, Nepal. J Ethnopharmacol. 1998;60(3):199-206.

4. Svarstad H, Dhillion SS. Responding to bioprospecting. From biodiversity in the south to medicines in the north. Spartacus Forlag; 2000.

5. Plotkin $M$, Famolare $L$, editors. Sustainable harvest and marketing of rain forest products. Island Press; 1992.

6. Taylor RS, Manandhar NP, Towers GH. Screening of selected medicinal plants of Nepal for antimicrobial activities. J Ethnopharmacol. 1995;46(3): 153-9.

7. Balick MJ, Elisabetsky E, Laird SA. Medicinal resources of the tropical forest: biodiversity and its importance to human health. New York: Columbia University Press; 1996.

8. Kebede D, Alemayehu A, Binyam G, Yunis M. A historical overview of traditional medicine practices and policy in Ethiopia. Ethiop J Health Dev. 2006;20(2):128-34.

9. Heinrich M, Kufer J, Leonti M, Pardo-de-Santayana M. Ethnobotany and ethnopharmacology interdisciplinary links with the historical sciences. J Ethnopharmacol. 2006;107(2):157-60.

10. Hamayun M, Khan MA, Begum S. Marketing of medicinal plants of UtrorGabral valleys, Swat Pakistan. Ethnobot Leafl. 2003;1:13.

11. Ali SI. Significance of flora with special reference to Pakistan. Pak J Bot. 2008; 40(3):967-71.

12. Akhtar N, Rashid A, Murad W, Bergmeier E. Diversity and use of ethnomedicinal plants in the region of Swat, North Pakistan. J Ethnobiol Ethnomed. 2013;9(1):25.

13. Abbasi AM, Khan MA, Shah MH, Shah MM, Pervez A, Ahmad M. Ethnobotanical appraisal and cultural values of medicinally important wild edible vegetables of Lesser Himalayas-Pakistan. J Ethnopharmacol. 2013;9(1):66.

14. Khan MZ, Khan RA, Ahmed M, Muhammad N, Khan MR, Khan HU, Atlas N, Khan FU. Biological screening of methanolic crude extracts of Caralluma tuberculata. Int J Indigenous Med Plants. 2013;46:2051-4263.

15. Ahmad M, Sultana S, Fazl-i-Hadi S, Ben Hadda T, Rashid S, Zafar M, Khan MA, Khan MP, Yaseen G. An Ethnobotanical study of medicinal plants in high mountainous region of Chail valley (District Swat-Pakistan). J Ethnobiol Ethnomed. 2014;10(1):36.

16. Amjad MS, Arshad M. Ethnobotanical inventory and medicinal uses of some important woody plant species of Kotli, Azad Kashmir, Pakistan. Asian Pac J Trop Biomed. 2014;4(12):952-8.

17. Bano A, Ahmad M, Hadda TB, Saboor A, Sultana S, Zafar M, Khan MP, Arshad M, Ashraf MA. Quantitative ethnomedicinal study of plants used in the Skardu valley at high altitude of Karakoram-Himalayan range, Pakistan. J Ethnobiol Ethnomed. 2014;10(1):43.

18. Aziz MA, Adnan M, Khan AH, Rehman AU, Jan R, Khan J. Ethno-medicinal survey of important plants practiced by indigenous community at Ladha subdivision, South Waziristan agency, Pakistan. J Ethnobiol Ethnomed. 2016;12(1):53.

19. Aziz MA, Khan AH, Adnan M, Izatullah I. Traditional uses of medicinal plants reported by the indigenous communities and local herbal practitioners of Bajaur Agency, Federally Administrated Tribal Areas Pakistan. J Ethnopharmacol. 2017;198:268-81.

20. Mahmood A, Mahmood A, Shaheen H, Qureshi RA, Sangi Y, Gilani SA. Ethnomedicinal survey of plants from district Bhimber Azad Jammu and Kashmir, Pakistan. J Med Arom Plants. 2011;5(11):2348-60.
21. Mahmood A, Mahmood A, Tabassum A. Ethnomedicinal survey of plants from District Sialkot Pakistan. J Appl Pharm. 2011;3:212-20.

22. Sher H, Aldosari A, Ali A, de Boer HJ. Indigenous knowledge of folk medicines among tribal minorities in Khyber Pakhtunkhwa, northwestern Pakistan. J Ethnopharmacol. 2015;166:157-67.

23. Chaudhry IS, Malik S, Ashraf M. Rural poverty in Pakistan: some related concepts, issues and empirical analysis. Pak Econ Soc Rev. 2006;1:259-76.

24. Martin GJ. Ethnobotany: a methods manual. London: Chapman and Hall; 1995.

25. Moerman DE. Symbols and selectivity: a statistical analysis of native American medical ethnobotany. J Ethnopharmacol. 1979;1(2):111-9.

26. Čančarević A, Bugarski B, Šavikin K, Zdunić G. Biological activity and ethnomedicinal use of Thymus vulgaris and Thymus serpyllum. Lekovite sirovine. 2013;33:3-17.

27. Heinrich M, Ankli A, Frei B, Weimann C, Sticher O. Medicinal plants in Mexico: Healers' consensus and cultural importance. Soc Sci Med. 1998; 47(11):1859-71.

28. Leonti M, Nebel S, Rivera D, Heinrich M. Wild gathered food plants in the European Mediterranean: a comparative analysis. Econ Bot. 2006;60(2):130-42.

29. Leonti M, Casu L, Sanna F, Bonsignore L. A comparison of medicinal plant use in Sardinia and Sicily_De Materia Medica revisited? J Ethnopharmacol. 2009;121(2):255-67.

30. Leonti M, Cabras S, Weckerle CS, Solinas MN, Casu L. The causal dependence of present plant knowledge on herbals-contemporary medicinal plant use in Campania (Italy) compared to Matthioli (1568). J Ethnopharmacol. 2010;130(2):379-91.

31. Lardos A, Heinrich M. Continuity and change in medicinal plant use: the example of monasteries on Cyprus and historical iatrosophia texts. J Ethnopharmacol. 2013;150(1):202-14.

32. Gairola S, Sharma J, Bedi YS. A cross-cultural analysis of Jammu, Kashmir and Ladakh (India) medicinal plant use. J Ethnopharmacol. 2014;155(2):925-86.

33. Pieroni A, Houlihan L, Ansari N, Hussain B, Aslam S. Medicinal perceptions of vegetables traditionally consumed by South-Asian migrants living in Bradford, Northern England. J Ethnopharmacol. 2007;113(1):100-10.

34. Bussmann RW, Sharon D. Traditional medicinal plant use in Northern Peru: tracking two thousand years of healing culture. J Ethnobiol Ethnomed. 2006;2(1):47

35. Zavaleta ES, Hulvey KB. Realistic species losses disproportionately reduce grassland resistance to biological invaders. Sci. 2004;306:1175-7.

36. Adnan M, Ullah I, Tariq A, Murad W, Azizullah A, Khan AL, Ali N. Ethnomedicine use in the war affected region of northwest Pakistan. J Ethnobiol Ethnomed. 2014;10(1):16.

37. Tolossa K, Debela E, Athanasiadou S, Tolera A, Ganga G, Houdijk JG. Ethnomedicinal study of plants used for treatment of human and livestock ailments by traditional healers in South Omo, Southern Ethiopia. J Ethnobiol Ethnomed. 2013;9(1):32.

38. Gorsi MS, Miraj S. Ethnomedicinal survey of plants of Khanabad village and its allied areas, district Gilgit. Asian J Plant Sci. 2002;1(5):604-15.

39. Abbas Q, Qureshi R, Naqvi AU, Khan SW, Hussain IS. Floristic inventory and ethnobotanical study of the Naltar valley (Karakoram Range), Gilgit, Pakistan. Pak J Bot. 2013:45:269-77.

40. Gazzaneo LR, De Lucena RF, de Albuquerque UP. Knowledge and use of medicinal plants by local specialists in an region of Atlantic Forest in the state of Pernambuco (Northeastern Brazil). J Ethnobiol Ethnomed. 2005;1(1):9.

41. Tugume P, Kakudidi EK, Buyinza M, Namaalwa J, Kamatenesi M, Mucunguzi P, Kalema J. Ethnobotanical survey of medicinal plant species used by communities around Mabira Central Forest Reserve, Uganda. J Ethnobiol Ethnomed. 2016;12(1):5.

42. Ahmad B, Rehman AU, Malik S. Consanguinity and inbreeding coefficient in tribal Pashtuns inhabiting the turbulent and war-affected territory of Bajaur Agency, North-West Pakistan. J Biosoc Sci. 2016;48(1):113-28.

43. Ullah M, Khan MU, Mahmood A, Malik RN, Hussain M, Wazir SM, Daud M, Shinwari ZK. An ethnobotanical survey of indigenous medicinal plants in Wana district south Waziristan agency Pakistan. J Ethnopharmacol. 2013; 150(3):918-24.

44. Mahishi P, Srinivasa BH, Shivanna MB. Medicinal plant wealth of local communities in some villages in Shimoga District of Karnataka India. J Ethnopharmacol. 2005:98(3):307-12

45. González JA, García-Barriuso M, Amich F. Ethnobotanical study of medicinal plants traditionally used in the Arribes del Duero, western Spain. J Ethnopharmacol. 2010;131(2):343-55. 
46. Miraldi E, Ferri S, Mostaghimi V. Botanical drugs and preparations in the traditional medicine of West Azerbaijan (Iran). J Ethnopharmacol. 2001; 75(2):77-87.

47. Ghorbani A. Studies on pharmaceutical ethnobotany in the region of Turkmen Sahra, north of Iran: (part 1) general results. J Ethnopharmacol. 2005;102(1):58-68.

48. Wesołowska A, Grzeszczuk M, Jadczak D, Nawrotek P, Struk M. Comparison of the chemical composition and antimicrobial activity of Thymus serpyllum essential oils. Not Bot Horti Agrobo. 2015;43(2):432-8.

49. Ghorbani A, Langenberger G, Feng L, Sauerborn J. Ethnobotanical study of medicinal plants utilised by Hani ethnicity in Naban river watershed national nature reserve, Yunnan China. J Ethnopharmacol. 2011;134(3):651-67.

50. Macía MJ, García E, Vidaurre PJ. An ethnobotanical survey of medicinal plants commercialized in the markets of La Paz and El Alto, Bolivia. J Ethnopharmacol. 2005:97(2):337-50.

51. Etana B: Ethnobotanical study of traditional medicinal plants of Goma Woreda, Jimma zone of Oromia region. Ethiopia: MSc Thesis, Addis Ababa University; 2010.

52. Ridvan P, Ugur C, Kaan K, Denizhan UM, Zafer T. An ethnobotanical study on medicinal plants in Espiye and its surrounding (Giresun-Turkey). J Ethnopharmacol. 2015;163:1-11.

53. Scherrer AM, Motti R, Weckerle CS. Traditional plant use in the areas of Monte Vesole and Ascea, Cilento National Park (Campania, Southern Italy). J Ethnopharmacol. 2005;97(1):129-43.

54. Sher H, Bussmann RW, Hart R, de Boer HJ. Traditional use of medicinal plants among Kalasha, Ismaeli and Sunni groups in Chitral District, Khyber Pakhtunkhwa province Pakistan. J Ethnopharmacol. 2016;188:57-69.

55. Bibi T, Ahmad M, Tareen RB, Tareen NM, Jabeen R, Rehman SU, Sultana S, Zafar M, Yaseen G. Ethnobotany of medicinal plants in district Mastung of Balochistan province-Pakistan. J Ethnopharmacol. 2014;157:79-89.

56. Khan I, AbdElsalam NM, Fouad H, Tariq A, Ullah R, Adnan M. Application of ethnobotanical indices on the use of traditional medicines against common diseases. Evid Based Complement Alternat Med. 2014;20:2014.

57. Ankli A, Sticher O, Heinrich M. Medical ethnobotany of the Yucatec Maya: healers' consensus as a quantitative criterion. Econ Bot. 1999;53(2):144-60.

58. Bennett BC, Prance GT. Introduced plants in the indigenous pharmacopoeia of Northern South America. Econ Bot. 2001;54(1):90-102.

59. Mosaddegh M, Naghibi F, Moazzeni H, Pirani A, Esmaeili S. Ethnobotanical survey of herbal remedies traditionally used in Kohghiluyeh va Boyer Ahmad province of Iran. J Ethnopharmacol. 2012;141(1):80-95.

60. Nasab FK, Khosravi AR. Ethnobotanical study of medicinal plants of Sirjan in Kerman Province, Iran. J Ethnopharmacol. 2014;154(1):190-7.

61. Heinrich M, Gibbons S. Ethnopharmacology in drug discovery: an analysis of its role and potential contribution. J Pharm Pharmacol. 2001;53(4):425-32.

62. Ali H, Sannai J, Sher H, Rashid A. Ethnobotanical profile of some plant resources in Malam Jabba valley of Swat, Pakistan. J Med Plants Res. 2011; 5(18):4676-87.

63. Safa O, Soltanipoor MA, Rastegar S, Kazemi M, Dehkordi KN, Ghannadi A. An ethnobotanical survey on hormozgan province, Iran. Avicenna J Phytomed. 2013:3(1):64

64. Shah A, Marwat SK, Gohar F, Khan A, Bhatti KH, Amin M, Din NU, Ahmad M, Zafar M. Ethnobotanical study of medicinal plants of semi-tribal area of Makerwal \& Gulla Khel (lying between Khyber Pakhtunkhwa and Punjab Provinces), Pakistan. Am J Plant Sci. 2013;4(01):98.

65. Karuppusamy S. Medicinal plants used by Palyan tribe of Sirumalai Hills of Southern India. Nat Prod Rad. 2007;6:436-42.

66. Marwat SK, Khan IU. Tracing the useful ethno phytomedicinal recipes of angiosperms used against jaundice and hepatitis in Indo-Pak subcontinent. World Appl Sci J. 2012;18:1243-52.

67. Shinwari ZK, Rehman M, Watanabe T, Yoshikawa Y. Medicinal and aromatic plants of Pakistan (a pictorial guide), vol. 492. Kohat University of Science and Technology, Pakistan; 2006

68. Shah A, Hussain S, Din NU, Bhatti KH, Khan A, Marwat SSK, Zafar M, Ahmad M. Sacred jungles: a traditional way of conserving endangered ecosystem and biodiversity in semi tribal are, Kurd sharif \& SHO (District Karak, Khyber Pakhtunkhwa) Pakistan. Sci Technol Dev. 2012:31:312-26.

69. Tareen RB, Bibi T, Khan MA, Ahmad M, Zafar M, Hina S. Indigenous knowledge of folk medicine by the women of Kalat and Khuzdar Regions of Balochistan, Pakistan. Pakistan J Bot. 2010;42(3):1465-85.

70. Sattar Abdel E, Harraz FM, Al-Ansari SM, El-Mekkawy S, Ichino C, Kiyohara H, Ishiyama A, Otoguro K, Omura S, Yamada H. Acylated pregnane glycosides from Caralluma tuberculata and their antiparasitic activity. Phytochemistry. 2008:69(11):2180-6.

71. Naik RM, Vaishnavi V, Preethi K, Krishnamurthy YL. Nutritive value and mineral composition of edible Caralluma and Boucerosia species from the arid areas of Karnataka. Int J Agric Environ Biotech. 2012;5:117-25.

72. Parekh J, Chanda S. In vitro antimicrobial activity and phytochemical analysis of some Indian medicinal plants. Turk J Biol. 2007;31(1):53-8.

73. Rauf A, Jan MR, Rehman WU, Muhammad N. Phytochemical, phytotoxic and antioxidant profile of Caralluma tuberculata NE Brown. Wudpecker. J Pharm Pharmacol. 2013;2(2):21-5

74. Waheed A, Barker J, Barton SJ, Khan GM, Najm-us-Saqib Q, Hussain M, Ahmed S, Owen C, Carew MA. Novel acylated steroidal glycosides from Caralluma tuberculata induce caspase-dependent apoptosis in cancer cells. J Ethnopharmacol. 2011;137(3):1189-96

75. Rizwani GH. Phytochemical and biological studies on medicinal herbs, Caralluma tuberculata and Caralluma edulis. A thesis submitted to the University of Karachi for the Degree of Doctor of Philosphy, Department of Pharmacogonosy, Faculty of Pharmacy, and University of Karachi, Pakistan; 1991.

76. Quave CL, Pardo-de-Santayana M, Pieroni A. Medical ethnobotany in Europe: from field ethnography to a more culturally sensitive evidencebased cam?. Evid Based Complement Alt Med. 2012.

77. Chevallier A, The Encyclopedia of Medicinal Plants, DK Publishing, University of Michigan, USA; 1996.

78. Pieroni A, Rexhepi B, Nedelcheva A, Hajdari A, Mustafa B, Kolosova V, Cianfaglione K, Quave CL. One century later: the folk botanical knowledge of the last remaining Albanians of the upper Reka Valley, Mount Korab Western Macedonia. J Ethnopharmacol. 2013;9(1):22.

79. Kayani S, Ahmad M, Zafar M, Sultana S, Khan MP, Ashraf MA, Hussain J, Yaseen G. Ethnobotanical uses of medicinal plants for respiratory disorders among the inhabitants of Gallies-Abbottabad Northern Pakistan. J Ethnopharmacol. 2014;156:47-60.

80. Redžić S. The ecological aspect of ethnobotany and ethnopharmacology of population in Bosnia and Herzegovina. Collegium antropologicum. 2007; 31(3):869-90.

81. Mustafa B, Hajdari A, Pieroni A, Pulaj B, Koro X, Quave CL. A cross-cultural comparison of folk plant uses among Albanians, Bosniaks, Gorani and Turks living in south Kosovo. J Ethnobiol Ethnomed. 2015;11(1):39.

82. Cappelletti EM, Trevisan R, Caniato R. External antirheumatic and antineuralgic herbal remedies in the traditional medicine of north-eastern Italy. J Ethnopharmacol. 1982;6(2):161-90.

83. Shinwari ZK, Gilani SS. Sustainable harvest of medicinal plants at Bulashbar Nullah, Astore (northern Pakistan). J Ethnopharmacol. 2003;84(2):289-98.

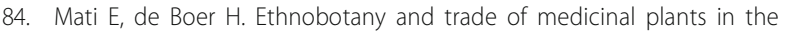
Qaysari Market, Kurdish Autonomous Region, Iraq. J Ethnopharmacol. 2011;133(2):490-510.

85. Benitez G, González-Tejero MR, Molero-Mesa J. Pharmaceutical ethnobotany in the western part of Granada province (southern Spain): ethnopharmacological synthesis. J Ethnopharmacol. 2010;129(1):87-105.

86. Kozuharova E, Lebanova H, Getov I, Benbassat N, Napier J. Descriptive study of contemporary status of the traditional knowledge on medicinal plants in Bulgaria. J Pharm Pharmacol. 2013;7(5):185-98.

87. Raal A, Paaver U, Arak E, Orav A. Content and composition of the essential oil of Thymus serpyllum L. growing wild in Estonia. Medicina (Kaunas). 2004; 40(8):795-800

88. Ahmad AM, Khokhar I, Ahmad I, Kashmiri MA, Adnan A, Ahmad M. Study of antimicrobial activity and composition by GC/MS spectroscopic analysis of the essential oil of Thymus serpyllum. Int J Food Saf. 2006;5:56-60.

89. Hussain Al, Anwar F, Chatha SA, Latif S, Sherazi ST, Ahmad A, Worthington J, Sarker SD. Chemical composition and bioactivity studies of the essential oils from two Thymus species from the Pakistani flora. Food Sci Technol. 2013; 50(1):185-92.

90. Stanisavljević DM, Zlatković BP, Ristić MS, Veličković DT, Đorđević SM, Lazić ML. The chemical composition of the essential oil of (Thymus Serpyllum L.) from Kopaonik mountain. Savremene tehnologije. 2012;1(1):25-9.

91. Petrović SS, Ristić MS, Petrović NV, Lazić ML, Francišković M, Petrović SD. Chemical composition and antioxidative activity of essential oil of Thymus serpyllum L. Hemijska industrija. 2014;68(3):389-97.

92. Thomson PDR Staff, editor. PDR for herbal medicines. Physician's Desk Reference (PDR); 2004.

93. Council of Europe European (COE) and European Directorate for the Quality of Medicines (EDQM), European Pharmacopoeia, Council of Europe 
European (COE), European Directorate for the Quality of Medicines (EDQM), Strasbourg, France, 6th edition, 2008.

94. Wichtl M. Herbal drugs and phytopharmaceuticals. Med Pharm Scientific Publishers, Stuttgart, Germany; 2001.

95. Kulisic T, Radonic A, Milos M. Inhibition of lard oxidation by fractions of different essential oils. Grasay Aceites. 2005;56(4):284-91.

96. Hazzit M, Baaliouamer A, Veríssimo AR, Faleiro ML, Miguel MG. Chemical composition and biological activities of Algerian Thymus oils. Food Chem. 2009;116(3):714-21.

97. Kavita G, Santosh K, Reeta S. Evaluation of antibacterial activity of aerial parts of Thymus serpyllum L. J Pharm Res. 2011;4:641-2.

98. Levi JC, Cabarkapa I, Todorovi GC. In vitro antibacterial activity of essential oils from plant family Lamiaceae. Rom Biotech Lett. 2011;16(2):6034-41.

99. Baig S, Ahma BA, Azizan AH, Ali SHM, Rouhollahi E, Abdulla MA. Hexane extract of Thymus serpyllum L.: GC-MS profile, antioxidant potential and anticancer impact on HepG2 (liver carcinoma) cell line. Int Sci Index. 2014;8:1518-25.

100. Kumar VP, Chauhan NS, Padh H, Rajani M. Search for antibacterial and antifungal agents from selected Indian medicinal plants. J Ethnopharmacol. 2006;107(2):182-8.

101. Sweta P, Kashyap RS, Deopujari JY, Purohit HJ, Taori GM, Daginawala HF. Effect of Fagonia Arabica (Dhamasa) on in vitro thrombolysis. BMC Complement Alter Med. 2007:7(1):36.

102. Adnan M, Jan S, Mussarat S, Tariq A, Begum S, Afroz A, Shinwari ZK. A review on ethnobotany phytochemistry and pharmacology of plant genus Caralluma R Br. J Pharm Pharmacol. 2013;66(10):1351-368.

103. Khattak KF. Microbiological quality assessment of commercially available medicinal plants in Peshawar city, Pakistan. Pak J Bot. 2012;44(4):1203-8.

104. Hsan A, Hussain, Zia M, Mirza B. Cytotoxic and antitumor potential of Fagonia cretica L. Turk J Biol. 2007;31(1):19-24.

105. Kasture VS, Gosavi SA, Kolpe JB, Deshapande SG. Phytochemical and biological evaluation of Fagonia species: a review. Int J Pharm Pharm Sci. 2014;3:1206-17.

106. Lam M. Cytotoxic activity of Fagonia cretica against human breast cancer cells. Ph.D diss., Aston University, UK; 2012.

107. Razi TM, Asad MH, Khan T, Zabta Chaudhary M, Tayyab Ansari M, Arshad MA Saqib QN. Antihaemorrhagic potentials of Fagonia cretica against Naja naja karachiensis (black Pakistan cobra) venom. Nat Prod Res. 2011;25(20):1902-7.

108. Gehlot D, Bohra A. Toxic effect of various plant part extracts on the causal organism of typhoid fever. Curr Sci. 2000;78:780-1.

109. Dastagir G, Hussain F, Khan AA. Antibacterial activity of some selected plants of family Zygophyllaceae and Euphorbiaceae. J Med Plants Res. 2012; 6(40):5360-8.

110. Sajid B, Alia E, Rizwana K, Uzma S, Alamgeer HM. Phytochemical screening and antimicrobial activity of Fagonia cretica plant extracts against selected microbes. J Pharm Res. 2011;4(4):962-3.

111. Eman AA. Morphological, phytochemical and biological screening on three Egyptian species of Fagonia. Acad Arena. 2011;3:18-27.

112. Anjum Ml, Ahmed E, Jabbar A, Malik A, Ashraf M, Moazzam M, Rasool MA. Antimicrobial constituents from Fagonia cretica. J Chem Soc Pak. 2007:29(6):634-9.

113. Khalid M, Muhammad B, Danial H, Shah Z, Danfeng H. Characterization of ethno-medicinal plant resources of Karamar valley Swabi, Pakistan. J Radiat Res Appl Sci. 2017;10(2):152-63.

114. Alemu F, Andualem B. Antimicrobial potentials of different solvent extracts of Justicia landonoides and Plantago lanceolata against standard and drug resistant human bacterial pathogens. Int J Microbiol Res. 2014;5(1):06-18

115. Ferrazzano GF, Cantile T, Roberto L, Ingenito A, Catania MR, Roscetto E, Palumbo G, Zarrelli A, Pollio A. Determination of the in vitro and in vivo antimicrobial activity on salivary Streptococci and Lactobacilli and chemical characterization of the phenolic content of a Plantago lanceolata infusion. Biomed Res Int. 2015;12

116. Arshad M, Ahmad M, Ahmed E, Saboor A, Abbas A, Sadiq S. An ethnobiological study in Kala Chitta hills of Pothwar region, Pakistan: multinomial logit specification. J Ethnobiol Ethnomed. 2014;10(1):13.

117. Bibi T, Ahmad M, Tareen NM, Jabeen R, Sultana S, Zafar M, Zain-ul-Abidin S. The endemic medicinal plants of Northern Balochistan, Pakistan and their uses in traditional medicine. J Ethnopharmacol 2015;173:1-0.

118. Abbasi AM, Khan MA, Ahmad M, Zafar M, Jahan S, Sultana S. Ethnopharmacological application of medicinal plants to cure skin diseases and in folk cosmetics among the tribal communities of North-West Frontier Province Pakistan. J Ethnopharmacol. 2010;128(2):322-35.

119. Ali Sl, Qaiser, MA. Phytogeographical analysis of the phanerogams of Pakistan and Kashmir. Proceedings of the Royal Society of Edinburgh. Section B: Biological Sciences. 1986;89:89-101.

120. Hadi F, Ibrar M. Ethnobotanical profile of gymnospermic flora of Kalash Valley district Chitral Hindo Kush range Pakistan. American-Eurasian. J Agri Environ Sci. 2014;14(12):1405-8.

121. Hamayun M, Khan A, Afzal S, Khan MA. Study on traditional knowledge and utility of medicinal herbs of district Buner, NWFP. Pakistan. 2006; 47(11):1859-71.

122. Hussain F, Islam M, Zaman A. Ethnobotanical profile of plants of Shawar Valley, District Swat Pakistan. Int J Biol Biotechnol. 2006;3(2):301-7.

123. Khan BA, Abdukadir A, Qureshi R, Mustafa GH. Medicinal uses of plants by the inhabitants of Khunjerab National Park, Gilgit, Pakistan. Pak J Bot. 2011; 43(5):2301-10.

124. Sher H, Khan ZD, Khan AU, Hussain F, ShengJi P. Ethnobotanical study on some plants in village Tigdari, district Swat Pakistan. Acta Bot. 2004:42-54.

125. Soelberg J, Jäger AK. Comparative ethnobotany of the Wakhi agropastoralist and the Kyrgyz nomads of Afghanistan. J Ethnobiol Ethnomed. 2016;12:1.

126. Balemie K, Kebebew F. Ethnobotanical study of wild edible plants in Derashe and Kucha Districts, South Ethiopia. J Ethnobiol Ethnomed. 2006;2(1):53.

\section{Submit your next manuscript to BioMed Central and we will help you at every step:}

- We accept pre-submission inquiries

- Our selector tool helps you to find the most relevant journal

- We provide round the clock customer support

- Convenient online submission

- Thorough peer review

- Inclusion in PubMed and all major indexing services

- Maximum visibility for your research

Submit your manuscript at www.biomedcentral.com/submit
Biomed Central 